\title{
Ações Afirmativas para Estudantes Quilombolas: o processo de criação do Programa de Inclusão de Estudantes Quilombolas (PROINQ) na Universidade Federal de Mato Grosso (UFMT)
}

SÔNIA REGINA LOURENÇO

O estado de Mato Grosso reúne um expressivo contingente de 97 comunidades de quilombos. Desse total, 69 abriram processo no INCRA, reivindicando a titulação fundiária de seus territórios tradicionais. Vale destacar que nenhuma das comunidades de quilombos no estado de Mato Grosso recebeu a titulação de seu território. Em todo o Brasil, a Fundação Cultural Palmares (FCP) mapeou 3.524 comunidades quilombolas. Destas, cerca de 1.500 foram reconhecidas e certificadas. No estado de Mato Grosso, estão distribuídas nos municípios de Cuiabá, Vila Bela da Santíssima Trindade, Cáceres, Nossa Senhora do Livramento, Chapada dos Guimarães, Acorizal, Barra do Bugres e Poconé - esta última concentra a maior parte, com 28 comunidades quilombolas, considerando o complexo de Mata-Cavalo, com seis núcleos. Só o município de Chapada dos Guimarães, mais conhecido pelo Parque Nacional de Chapada dos Guimarães e pelo circuito turístico, abriga, nos sertões adentro, os quilombos Ribeirão Itambé, Lagoinha de Baixo, Lagoinha de Cima, Ariçá-Açu, Morro do Cambambi, Mata Grande e Cansanção. Em Cambambi, por exemplo, a comunidade é constituída por uma rede extensa de famílias, "esparramadas", como eles dizem, nas proximidades do Rio Quilombo, na Biquinha, com 18 famílias, em Varginha e no próprio Morro do Cambambi, lugares nos quais "nasceram e foram criados". As famílias de todos os quilombos de Chapada dos Guimarães totalizam aproximadamente 2,5 mil famílias, "esparramadas" nas áreas rurais e urbanizadas na cidade e nos bairros periféricos das cidades de Cuiabá e Várzea Grande. 
Estas comunidades estão conectadas pelas relações de parentesco, pelas trocas que se adensam com as festas de santo que fazem circular a pequena produção de mandioca para a produção de farinha, o maxixe, a coleta de coco de babaçu, os doces de caju e de banana, entre outros temperos e receitas da culinária dos quilombos, que confere às festas o saber local. Neste circuito de trocas, os itinerários terapêuticos e as práticas de autocuidado promovidos pelas mulheres benzedeiras e raizeiras reafirmam também a importância da terra e a contiguidade territorial entre os quilombos, configurando uma linha contínua entre elas, a terra, o território tradicional e as cosmologias.

Assim, fazem dos sertões de Chapada dos Guimarães uma grande “territorialidade negra”, expressão que Maria de Lourdes Bandeira (1991) cunhou para definir as terras de quilombos. "Territorialidade negra" que existe e (re)existe a despeito das grandes plantações de soja, de milho, de algodão, de eucalipto e da criação de gado da economia capitalística do agronegócio que avança sobre os territórios tradicionais. Esta territorialidade circunscreve não apenas uma dimensão geográfica da terra, mas a expressão de alteridades que as forças unificadoras do Estado e do racismo ambiental e institucional tentaram obstruir.

As pesquisas realizadas com estas comunidades permitem aferir que o Centro-Oeste foi um epicentro do sistema escravista colonial que buscou dominar e colonizar tanto os povos indígenas quanto a população africana, e, posteriormente, os afrodescendentes que formaram a maioria da população em todo o território brasileiro. Alguns quilombos marcaram o contexto histórico dos séculos XVIII e XIX no estado de Mato Grosso: o maior quilombo de todos, chamado Quariterê ou Piolho, o quilombo de Sepotuba e o quilombo de Rio do Manso, localizado em Chapada dos Guimarães, formado antes de 1859. No ano de 1770, as constantes notícias de fugas de escravos para o mato e para o quilombo Grande, o Quariterê, fizeram com que o governador da província, Luís Pinto de Souza Coutinho, criasse uma companhia de soldados, ordenando a destruição do quilombo, recomendando ao sargento-mor "o inviolável segredo que devia haver na saída para o tal quilombo, a fim de que os negros não tivessem notícia dessa nunca pensada determinação" (Anzai \& Amado 2006:138). Assim, na noite de 22 de julho do ano de 1770, a companhia de soldados partiu para a aniquilação do quilombo de Quariterê, conforme a narrativa oficial, registrada nos Anais de Vila Bela,

"Rompendo os sertões e veredas mais agrestes, animosamente chegaram ao afamado quilombo Grande. E o abalroaram na noite de 22 de julho. Por estarem as casas do quilombo divididas e dispersas umas das outras, em diferentes partes, abalroaram a primeira que toparam, onde surpreenderam muito pouca gente (...). Sendo os encontros muitos, e muitas resistências, não houve da nossa parte perigo algum de vida. Da parte daqueles infiéis morreram nove, dos quais foram apresentadas ao Senado 18 orelhas. Compunha-se esse quilombo de 69 pessoas do gênio de Guiné, entre machos e fêmeas, dos quais vieram acorrentados e presos 41, e nove mortos; perfazem cinquenta; e os 37 que faltam, para o total de escravos, ficaram desarvorados pelos matos. Achavam-se no mesmo quilombo trinta e tantas índias, que os tais negros tinham apanhado no sertão, onde matavam os machos e traziam as fêmeas para delas usar como mulheres próprias" (Anzai \& Amado 2006:139-141, grifos meus). 
O quilombo Grande, Quariterê ou Piolho, foi liderado por Teresa de Benguela, a rainha negra e ex-escrava. Teresa de Benguela governou o quilombo por mais de 20 anos após o assassinato de seu marido, José Piolho, que ocupava a posição de rei no Quariterê. No dia 25 de julho se celebra o Dia Internacional da Mulher Negra Latino-Americana e Caribenha, oficialmente reconhecido com a Lei $\mathrm{n}^{\circ}$. 12.987, de 2 de junho de 2014, instituindo o Dia Nacional de Tereza de Benguela e da Mulher Negra. A data foi estabelecida em 1992, no I Encontro de Mulheres Afro-Latino-Americanas e Afro-Caribenhas.

A narrativa documentada nos Anais fornece não apenas os sinais da presença do contingente africano escravizado na região do Rio Guaporé, mas também a resistência dos quilombos ao aprisionamento e à servidão colonial. Teresa de Benguela foi aprisionada, cortaram-lhe a cabeça e a penduraram num poste no meio da praça do quilombo, como exemplo da ação da coroa contra a resistência. $\mathrm{O}$ quilombo, de maioria constituída por “índios caborés” e negros que sobreviveram à primeira expedição bandeirante nos rios Guaporé e São José (Piolho), foi transferido para outro assentamento, chamado Aldeia Carlota. Neste lugar, teriam sido tomados como exemplo do regime disciplinar do poder colonial para controlar os "ataques" de indígenas e evitar novas fugas e retaliações de escravos.

Os quilombos localizados em Chapada dos Parecis, rios da Galera, Sararé, Mutuca e Pindaituba, além do quilombo de Quariterê, foram todos atacados e destruídos pelas companhias de soldados, as bandeiras, que seguiam ordens do governador da província, desejoso em consolidar o domínio sobre os territórios no interior do estado de Mato Grosso (Bandeira 1988:118).

A narrativa da sociedade colonial compreendia que o ato de se aquilombar ou se amocambar significava tanto se rebelar contra a legislação vigente quanto "apavorar" a população não escrava. $\mathrm{O}$ "medo negro" pode ser lido como uma chave interpretativa que tenta minimizar a agência dos sujeitos em situação de desigualdade social (Carneiro da Cunha 2012). A insurgência dos quilombos, considerada apenas como atos rebeldes de sujeitos desterrados e desenraizados de seus locais de origem, reaparece com as comunidades quilombolas reivindicando ações afirmativas como políticas públicas de Estado de acesso ao ensino superior como um direito.

As ações afirmativas para quilombos são políticas de reparação histórica, social e também de natureza étnico-racial, na medida em que o sistema de escravidão foi um sistema compulsório e hierárquico que teve "em si loci de violência e de opressão, que estavam eventualmente situados em pontos diferentes, em diferentes sociedades". Como argumenta Carneiro da Cunha (2012:77-84), "ser negro" era sinônimo de escravo e escravo era sinônimo de ser negro ou africano; talvez fosse uma das razões pelas quais os forros procuravam escapar do sistema, se juntando aos quilombos do interior de vários estados do Brasil, como forma de resistência e de rearranjo social de suas formas de vida. A população negra que conseguia a alforria e passava a viver na condição de pessoas livres, ainda assim, não conseguia o acesso à terra, à educação e à saúde. Esta exclusão fortalecia a concentração de terras e continuava a sujeitar a população "livre" ao trabalho dependente como assalariados e diaristas, agregados e lavradores em fazendas de cana, café, entre outras. Estas condições de trabalho são encontradas até os dias de hoje quando muitos trabalhadores e trabalhadoras quilombolas se encontram submetidos às relações de trabalho em fazendas, forjadas por grandes grileiros de terras, dentro dos territórios quilombolas 
e, sem carteira assinada e sem nenhuma garantia de direitos, acabam trabalhando para seus próprios antagonistas, uma forma de "cativeiro" contemporâneo. ${ }^{1}$

O Programa de Inclusão de Estudantes Quilombolas (PROINQ) tem como marco inicial a data de 7 de dezembro de 2013, quando foi realizado o Seminário Comunidades Quilombolas de Mato Grosso: território, educação e patrimônio cultural, realizado por mim e os alunos bolsistas de extensão (Foto 1$).^{2} \mathrm{O}$ evento teve a participação de oito comunidades de quilombos dos municípios de Chapada dos Guimarães, Poconé, Vila Bela da Santíssima Trindade, Várzea Grande e Nossa Senhora do Livramento, de representantes da Superintendência Regional do Instituto Nacional de Colonização e Reforma Agrária (INCRA, 13/MT), e da Coordenação de Políticas Acadêmicas e Ações Afirmativas da Pró-Reitoria de Assistência Estudantil - PRAE/UFMT. Todas as despesas com passagens e alimentação para propiciar a participação dos quilombolas no evento foram custeadas pelos recursos do edital PROEXT/2013.

O seminário tinha como objetivo realizar a devolutiva dos resultados das pesquisas e das ações de extensão desenvolvidas com as comunidades Lagoinha de Cima e Lagoinha de Baixo, quilombos que ali vivem há mais de 200 anos nas áreas rurais do município de Chapada dos Guimarães. Os dois quilombos foram reconhecidos e certificados pela Fundação Cultural Palmares no ano de 2005, no âmbito das políticas públicas para certificação e reconhecimento das comunidades quilombolas desde a publicação da Carta Constitucional, e do ADCT 68, que estabeleceu que "aos remanescentes das comunidades dos quilombos que estejam ocupando suas terras é reconhecida a propriedade definitiva, devendo o Estado emitir-lhes os títulos respectivos".

No período da manhã, faríamos a apresentação dos trabalhos de pesquisa e extensão, mas a dinâmica se inverteu, quando os quilombolas pegaram o microfone e resolveram contar as suas histórias, narrando os episódios de violência, de racismo, de ameaças e de resistência aos dispositivos de exclusão promovidos pelo Estado brasileiro durante os últimos dois séculos (XIX e XX). As narrativas dos representantes das comunidades quilombolas de Vale do Alegre Valentim e Martinho, de Vila Bela, Morro do Cambambi, Lagoinha de Baixo e Lagoinha de Cima, de Chapada dos Guimarães, Tanque do Padre, de Poconé, e Capão do Negro, de Várzea Grande, versam sobre o processo de expulsão de suas terras, os conflitos e as ações que eles têm empreendido na luta política por seus direitos aos territórios tradicionais e, agora, pelo acesso à educação no ensino superior. O primeiro deles a falar foi o Sr. Emídio de Souza, da comunidade Morro do Cambambi, importante representante das comunidades quilombolas no Conselho de Ações Afirmativas da UFMT, criado em maio de 2014. ${ }^{3}$

$1 \mathrm{O}$ monopólio sobre as terras se consolida no século XIX com a promulgação da Lei de Terras de 1850. Assim, proibia-se o acesso à terra da população negra e se alimentava a condição da escravidão que, por sua vez, era a principal força produtiva que sustentava o sistema econômico e político do Brasil desde meados do século XVI ao XIX.

2 O Seminário foi uma das atividades previstas no projeto de extensão Patrimônio Cultural e Saberes tradicionais Quilombolas, Chapada dos Guimarães/MT, edital PROEXT/MEC, 2013.

3 Todas as falas foram gravadas e filmadas com a autorização prévia dos representantes quilombolas para finalidades acadêmicas. 
Sempre que eu vou junto aos encontros com Elzito, da Lagoinha de Baixo, a Rosinete, né, é um prazer muito grande, eu sou lá do Ribeirão Bom Jardim, Morro do Cambambi. Se eu for contar minha história é mais que cinco minutos, entendeu, porque quando eu ainda era pequeno as nossas terras forma tomadas à força, a peso de carabina, bem aqui pertinho, a 90 quilômetros de Cuiabá. Colocaram fogo em nossas casas foram pelos latifundiários que nunca plantaram um pé de quiabo. Os meus avós e bisavós desde 1900, 1850 ou 1853, viviam ali e em menos de quinze dias tudo foi para as cinzas. E eu ainda era pequeno. A gente terminou vindo para a cidade e meu avô foi acidentado, passou a beber, não conhecia a cidade, e assim veio o sofrimento. Aí que a gente começa a ver o povo lutando pelos seus direitos. Então não é muito diferente, nós do Morro do Cambambi, onde nós temos um pedacinho de terra, lá moram essas trinta e poucas famílias. Mas a nossa terra era muito maior, e $95 \%$ das terras nossas foram tomadas à força. E assim a gente sabe também que em outras regiões isso aconteceu e até inclusive se a gente for ver, a identidade de cada um está até perdida, sem identidade, por quê? Porque foi tomada a força, são situações em que nós precisamos unir as forças. Com isso parabenizo o encontro porque é uma forma de interagir e de nós conhecermos a realidade do outro. Porque, às vezes, a gente acha que é só Lagoinha de Baixo que passou, que está passando por dificuldade de legalidade do território, mas não. É Chapada, Poconé, Vila Bela, que dizer sessenta e seis [69 com processos abertos no INCRA] comunidades tradicionais em Mato Grosso estão precisando da união para poder garantir o seu território, a legalização de suas terras. Você entendeu? Quer dizer, a minha, de treze famílias, que era na época quando fomos expulsos, somando hoje até a quinta geração dá mais de mil e duzentas pessoas nas periferias do mundo de meu Deus. Aqui no Brasil, assim, são muitas. Então essa realidade precisa mudar, e para mudar nós recebemos professores levantando informação, os antropólogos para o trabalho que a antropologia faz ao registrar a nossa história e deixando mais claro, né (Emídio de Souza, 2013).

Em seguida, a fala de Berchman Leite Ribeiro, do quilombo Vale do Alegre Valentim e Martinho, de Vila Bela da Santíssima Trindade, conta a história de sua comunidade e do seu trabalho colaborativo como pesquisador e técnico agrimensor junto aos trabalhos de identificação e delimitação dos territórios quilombolas realizados com o INCRA.

Sou do Vale Alegre, Vale do Alegre por quê? Porque as famílias todas moravam no Rio Alegre e essas famílias que moravam no Rio Alegre, na região toda, eles todos foram expulsos. Aconteceu a mesma coisa, ainda tem um rapaz lá na Vila Bela, ele deve estar com 71 anos que tiraram ele da casa, amarraram e tocaram fogo na casa dele. E aí foi muito dessas assim, e Valentim Martins é o nome do meu avô. Martinho é outro homem do quilombo que nós tínhamos lá. E, digamos assim, hoje o nosso trabalho é muito pesado, pesado, eu fiz um trabalho lá para ver se nós construíamos. Vou mostrar para vocês, eu não tenho faculdade, os trabalhos começaram assim, no sistema artesanal (ele mostra o desenho da (Foto 1). Para poder chegar até o presidente da república nós chegaremos com esse documento lá. Mandei e chegou na mão dele. Na mão dele para reconhecer o nosso território onde já tinham tirado para todo lado. Nós estamos em cima do território e ganhei a carta de autoreconhecimento [da Fundação Cultural Palmares] em cima desse documento aí. E aí atrás estão todas as informações, aqui estão todas as informações. Todas as famílias, mais lá para frente nós temos um documento de quem morreu. Esse aqui é a carta, todos esses aqui. Mas foi 
um trabalho de muito sacrifício e até agora, por quê? Latifundiário quando dá um passo, ele dá dez, dá dez [...]. Fomos lá para Brasília, lá nos ministérios, eles acolhem a gente igual mãe acolhe a gente, igualzinho a mãe, ele obedece fala tudo o que você tem que fazer. Mas daí quando você vê que de uma parte que chega no nosso estado, eles desviam, nós temos que ver onde que esse desvio está. Entendeu? Porque na pele, vou falar de 1949. Foi uma das primeiras invasões das terras que pertenciam ao meu pai, desde a Segunda Guerra mundial, onde eles mandaram 1.200 arigó lá no Amazonas. Arigó é soldado. Soldado da borracha, aí de lá do Amazonas eles têm que ir trezentos e cinquenta mil de pau de óleo para a fazenda do governo federal, onde abriu a fazenda. Você sabe para quem que revoltou esse pessoal? Para nós que somos de Vila Bela. Não tinha estrada, não tinha uma saída, entendeu? O que que aconteceu? O latifundiário queria tudo, pegando nosso território, pegando nossa borracha, e a negrada vai para onde? E aí tem mais um ainda. Quem nunca tinha visto assim camarada falar assim "eu vou entrar na sua casa hoje". Eles faziam. Porque de Vila Bela para baixo era território que você não podia descer, em certas partes com as famílias que lá estavam. E daí de 1964 para cá, entrou em invasão de uma vez no território, o que acontecia, se eu estava lá muitas vezes é tomada mandada nas pessoas lá, eu conversava com você, esse território aqui ele está mandado por São Paulo, pode todo documento que fiz tem lá, ou do Paraná, de Minas, eles já vinham com documento pronto. Aí ele assentava em volta de onde nós morávamos. Agora você vai ter que me ajudar a fazer dez quilômetros de cerca. Como que eu ia ajudar se eu não tinha? Sabe o que acontecia? Expulsavam dali. Aí mandava "rapaz é melhor o senhor sair dali, porque a vaca dele vai te atrapalhar, você está no meio da terra dele e não tem condição”. Ele te dava lá para você cinco reais, aí fazia você assinar um recibo como que vendeu, que injusto uma coisa dessas. Aí ou pedia até o nome, que você não podia nada, como que você ia falar, não tinha como. Aí está. Aí veio em 1988 agora o direito do negro. Mas eu não vi esse direito até agora. Eu não vi. Então, companheiros e companheiras, nós temos que dar as mãos um para o outro e falar: vamos juntos. Vamos juntos. Vamos segurar um na mão do outro que quando nós seguramos a mão do outro, o pessoal aí se abre. Se abre, aí nós damos conta. Sou capaz de escrever desde que aconteceu tudo lá, entendeu, agora de onde que nós viemos, vai chegar nesse ponto. Até em Vila Bela hoje, ou no passado, foi a capital de Mato Grosso, e aonde tem a maior jazida de ouro no Brasil, foi Serra Pelada e Vila Bela. Está lá, o cara está arrancando mais de quarenta toneladas por ano de ouro. Nas terras quilombolas, lá em cima, em cima de Vila Bela. No território de Vila Bela, e nós negros de Vila Bela não podemos falar, não temos direitos de ir lá. Então está aí a resposta. Entendeu? Mas chega, chega de nós sofrermos. Deixaram nós lá naquele lugar de Vila Bela sem resposta nenhuma até o governo estadual, o governo federal, e nós não vemos até hoje. Porque que não olhou nessa parte quilombola. Cuiabá entrou nessa questão com Campo Grande de mudar a capital para lá, Márcio Lacerda entrou com um documento, recurso que ele pagou para lá, eles devolveram e para nós de Vila Bela para dar como capital e está lá até hoje. Foi jogado lá, e nós estamos arrastando até agora, entendeu? Mas não está batendo a ideia assim diretamente como eu estou falando, não está batendo (Berchman Leite Ribeiro). 


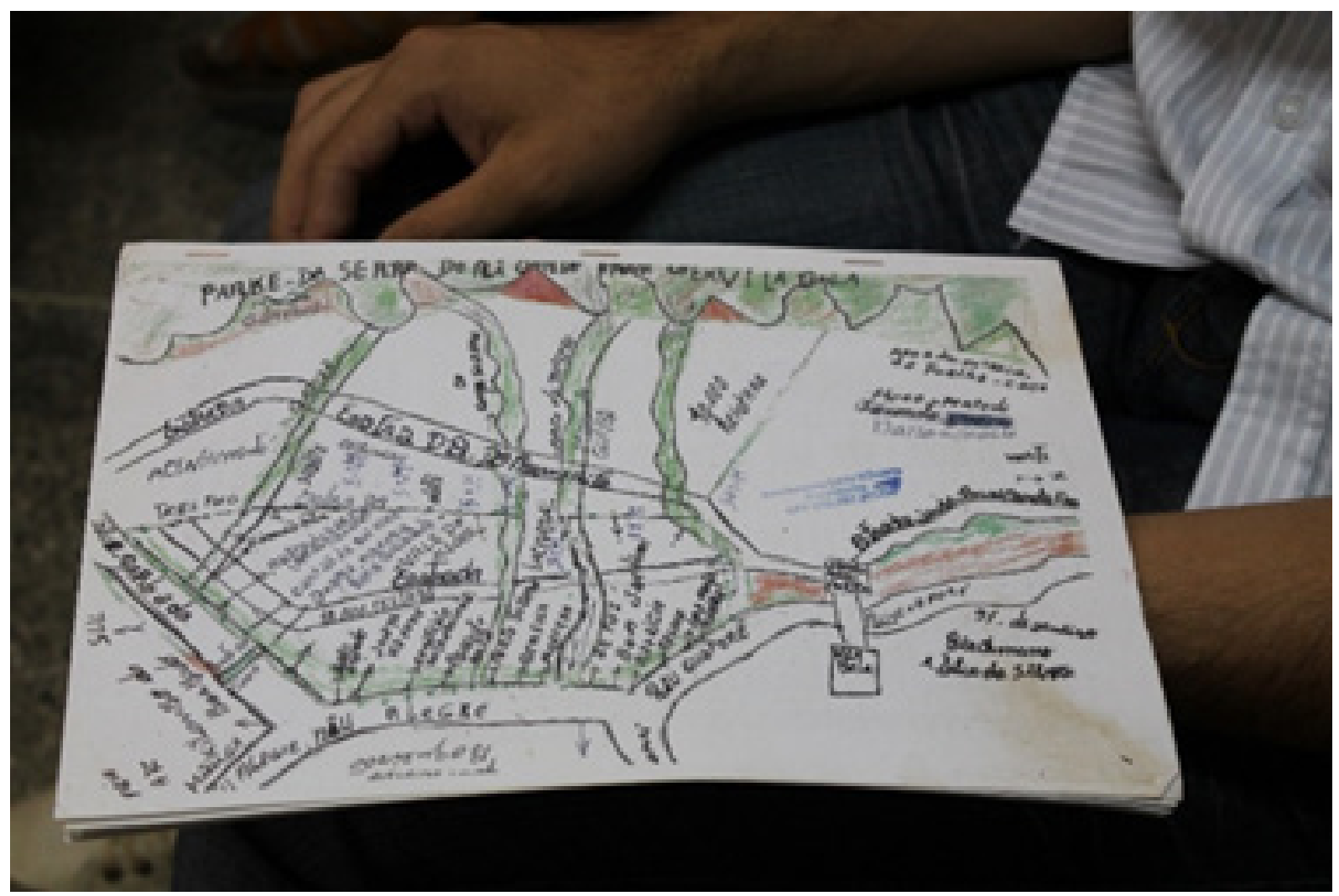

Foto 1: Cartografia elaborada por Berchman Leite Ribeiro Vale do Alegre Valentim e Martinho, de Vila Bela, MT. Seminário Comunidades Quilombolas de Mato Grosso: território, educação e patrimônio cultural, 07 de dezembro de 20113, ICHS, UFMT. Acervo Pessoal.

Dona Amância Frazão, importante Capelã das Irmandades que promovem a Festança, um conjunto de festas dedicadas a São Benedito, ao Divino Espírito Santo e às Três Pessoas da Santíssima Trindade durante o mês de julho, faz um importante relato sobre as expropriaçóes das terras de quilombo:

Eu nasci no sítio, com meu irmão, e criamos, crescemos no sítio. Lá tinha de tudo, primeiramente era paz, né, na beira do rio, lindo rio. Tinha roça, tinha de tudo. Quando foi de umas mediações para cá, foram aparecendo aqueles fazendeiros, falaram que a terra eram deles e assim, que comprou de fulano de tal que não sabia quem era quem. Até porque nós não tínhamos o conhecimento desse fazendeiro, né. Quando nós chegamos, eles tomaram as terras tudinho. Como lá era nosso, saímos de lá, ficaram todas as coisas e nós viemos ficar na cidade sem um palmo de terra para plantar nada e sem nem direito de ir lá, né, proibiu a gente de ir. Quando de umas imediações para cá já não estava mais como estava antes assim, que desmataram muito e tiraram todas as famílias que tinham ali. Agora de uns tempos para cá já não estão mais assim, estão meio cismados, mas só quem tem dinheiro, tem dinheiro, quem não tem. Mas que nós sofremos, nós sofremos muito (Amância Frazão).

No diálogo com Berchman Leite Ribeiro, Emídio de Souza toma a palavra para fazer referência ao processo da escravidão e ao navio negreiro, estabelecendo conexões históricas e simbólicas com a África e o processo colonial: 
Você puxa lá pra África o que é negro, o que é o negro na África, o negro é um lá na África, é uma colônia, vamos dizer assim, eu falo sempre esse exemplo, aqui em Cuiabá fala inglês, ali no Livramento fala português, ali na Vila Bela fala francês, e em vários lugares e o que que aconteceu, trouxeram esses negros para cá e enclausuraram no navio negreiro, agora você imagina vários dialetos, vários problemas, você entendeu, então como se num local, e daí cada um falava uma língua, cada um arrastava sua cultura e acabava se expandido. Aí hoje se você olhar pra África, até hoje eles não sobressaem, não conseguem parar os conflitos, você vê aquela pobreza, aquela dificuldade tremenda, entendeu [...]. Então nós temos que parar com isso, vamos se unir as forças e vamos se abraçar e vamos partir para cima. Se vocês analisarem, segundo a história, tem muitas pessoas bem muito mais estudadas que eu, é noventa e cinco, é sessenta e cinco por cento da população que vive desatualizada, vive fora do meio são os negros, entendeu. E se você olhar para história são uma meia dúzia de negros, e aliás são meia dúzia de brancos que mandaram. Entendeu? Se aqueles negros lá, se eles soubessem a força que eles tinham, eles se reuniam e faziam, então está acontecendo a mesma coisa que eles se uniam, eles faziam. E está acontecendo a mesma coisa hoje, nós somos a maioria negros e aí nós não temos essa força, e deixamos a minoria que é o negro, é o Estado mandando em cima da gente (Emídio de Souza).

Elizeu da Silva pertence à comunidade Capão do Negro, situado na zona urbana da cidade de Várzea Grande, município limítrofe da cidade de Cuiabá. O território tradicional reivindicado pela comunidade Capão do Negro se encontra próximo do aeroporto Marechal Cândido Rondon,

E a nossa comunidade quilombola em Várzea Grande foi o palco de uma questão social que foi no Brasil de embranquecer o Brasil, aí que teve a Guerra do Paraguai em 1890, que o marido da Princesa Isabel mandou vir para cá os prisioneiros paraguaios e os soldados que eram os escravos. Então nós temos que bater nessa questão para você ver nós somos sessenta e oito comunidades quilombolas e a gente tem contato com poucas (Elizeu da Silva).

Rosário Leite da Costa, da comunidade Tanque do Padre, município de Poconé, ouvia atenta as narrativas dos outros e destaca a semelhança dos processos históricos e conflitos vividos por eles. Poconé possui 28 comunidades de quilombos. Destas, Tanque do Padre, Jejum e Laranjal têm os Relatórios de Identificação e Delimitação (RTID) finalizados, e publicado, apenas o relatório de Campina de Pedra.

Eu sou Rosário lá do município de Poconé, quilombola. Minha comunidade remanescente de quilombo é Tanque do Padre e eu estou observando a história deles, que é parecida com a nossa. Só que lá eles nos tratam de uma forma mais, como que eu posso dizer, mais civilizada. Houve uma medição, acho que em 1930, em Poconé. E o que fizeram, mediram todas as terras, e aí os fazendeiros tiraram deles, diminuíram as terras dos menos favorecidos, né. $\mathrm{E}$ aí então, do meu avô que era noventa e pouco, ficou trinta e pouco hectares. E foi diminuindo, assim aconteceu no município inteiro de Poconé, recolheram todas as escrituras e ficou lá. Aí veio uma série na época da reforma agrária parece que é assim de história, né, mandou que eles fossem retirar as escrituras. Foram lá e viram que estava tudo diminuída. Porque disseram, eles questionaram, eles disseram que não, os fazendeiros tinham que tirar os deles. Aí eles acharam que estavam na terra de quilombo. Então 
a gente vê assim não houve, não houve assim essas agressões, mas aconteceu isso também. Se você pára para pensar é a mesma história. São as mesmas histórias. Então eu acho assim que podia aquilo que o negro vem para o Brasil para quê? Para ser escravo, para trabalhar sem direito à educação, sem direito à moradia. Então eu penso comigo, né, ao meu ver, que negro quer com terra? Se veio para ser escravo, né, eu penso comigo, que deve ser isso, que foi usado dessa forma, mas que aconteceu perda de terra no município de Poconé (Rosário Leite da Costa).

Após a fala de Rosário, Tatiana Reis de Castro, da comunidade Lagoinha de Baixo, conta sobre as dificuldades em ter que trabalhar para os próprios fazendeiros que ocupam as terras de seus ancestrais.

Lá, para conseguir tomar foi o seguinte. Nós somos uma comunidade pequena. O serviço é de diária, ninguém lá trabalha mensal. Então para você comer tem que fazer um biquinho aqui, um biquinho ali, ou se você tiver uma coisa aqui você troca. Aí naquela época eu acho que foi perdendo a mão, os fazendeiros. Ah, preciso criar um gado, eu dou um conto desse pedacinho de terra, e foi diminuindo, diminuindo. - Ah, eu troco com você por uma carabina, o pessoal caçava na época para poder se alimentar. $\mathrm{E}$ aí foi indo, foi diminuindo as terras, foi diminuindo e hoje em dia a gente mora lá cada um em um cantinho desses. Aí quando saiu o decreto no Diário Oficial da União que ia devolver as terras, os fazendeiros ficaram todos doidos da vida, pois é uma coisa que nem era deles, eles nem pagaram para ter aquilo. Porque se desse o emprego para todo mundo. - Não, você está precisando, vou lá com você. Agora você trocar uma terra por causa de um pacote de arroz é um absurdo. Nosso avô tinha cento e dois hectares. Mais da minha avó tinha tantos, juntando os dois, foi trocando. Aquela parte do rio Lagoinha ali até o encontro, na direção do rio para cima era tudo da minha avó. Então todo mundo lá tinha terra. Hoje em dia ficou só os netos e tudo hoje da minha avó ficou naquele lugarzinho ali. Lá onde eu moro se for um hectare é muito. Aí só que meu marido tem uma roça para eu plantar, sempre está plantando lá no quintal, uma coisa ou outra, sempre está mexendo com a terra. Mas eu preciso do trabalho, aí é aquela coisa: te pago aí 20 reais a diária, se quiser. Aí você vai conseguindo, você vai sobrevivendo. Mas se não acha que estava todo mundo vivendo bem não (Tatiana Reis de Castro).

Em Chapada dos Guimarães, o único Relatório Antropológico $(2007)^{4}$ publicado é o de Lagoinha de Baixo, que reivindica a titulação de uma área de 2.514,966 hectares. Segundo os dados do Relatório daquele ano, a comunidade é formada por 92 indivíduos, 67 destes distribuídos em 17 casas. Em seguida, a irmã de Tatiana, Gonçalina Reis de Castro, continua a narrativa:

Meu avô mesmo, meu avô ganhou um pedaço de terra, tinha um pedaço de terra grande, e trocou por um pedacinho, um lote em uma fazendinha ao lado, trocou por nada, só por um pedacinho de terra.

4 Renata Bortoletto Silva \& Simone Gianotti. 2007. Relatório de Caracterização Sócio-Histórica e Antropológica Associação Quilombola Comunidade Negra Rural Lagoinha de Baixo, Chapada dos Guimarães (MT). Instituto Nacional de Colonização e Reforma Agrária (INCRA), Superintendência Regional de Mato Grosso SR/13, Cuiabá (MT). 
Cada narrativa desencadeava no outro o desejo de apresentar a perspectiva quilombola sobre a história, ou seja, como eles pensam, formulam e elaboram a sua versão da história (Gow 1991). O Sr. Emídio de Souza toma a palavra para lembrar que as terras de quilombo eram todas "terras devolutas", e que, nelas, os fundadores da comunidade cultivavam para a economia de subsistência e para as relações de troca entre os habitantes da área rural da região. Além disso, põe em evidência o período de grande violência na década de 1970, em plena ditadura militar, praticada contra as comunidades negras e outras populações tradicionais que foram expulsas de suas terras, tradicionalmente ocupadas, em todo o Brasil.

Estou observando o quanto é uma realidade de todas as situações dos territórios, praticamente parecidas, tudo semelhante, porque se a gente for buscar bem a fundo, quase todas essas áreas de onde é o território de quilombo, todas eram consideradas terras devolutas, você entendeu. E como era área devoluta antigamente, não legalizava, principalmente em nome dos negros; eu me lembro, em 1974 estava com nove anos de idade, somando vocês já vão saber minha idade, né. E se nove anos de idade eu me lembro, lá nas nossas terras eram 5.625 hectares, que eram hectares de áreas devolutas desde 1853 que meus avós, bisavós eram nascidos e criados lá. Eu só me lembro que chegou aquelas camionetes C-14 lotadas de peão, cada uma com uma carabina, eu era moleque assim e visitou assim, e visitou as casas, as 13 casas em volta da Serra do Cambambi, e deu 15 dias para que todos mudassem dali porque o fulano de tal teria comprado as terras, você entendeu. E ele mandou falar para o pessoal que tinha que desocupar em 15 dias senão ia tocar fogo com o pessoal dentro. E aí meu padrinho, que era mais forte um pouquinho, meu tio e padrinho, ele tinha umas cabeças de boi que ele trazia as tropas de lá da roça e vinha aqui para cidade. Vinte, trinta bois com carga de mantimento para levar sabão, querosene para lá. Então, ele que era o mais sabidinho da família. Aí ele pegou, vendeu, desceu com a tropa dele, vendeu a metade do gado dele, comprou uma pequena terra em outra regiáo lá mesmo em Chapada e saiu fora. Dentro dos 15 dias. E aí, quer dizer, os outros mais fracos ficaram fazendo o que? Tiraram as galinhas, tudinho, fora do limite da área devoluta e só ficou observando os jagunços tocando fogo, quinze jagunços, entendeu, todos, cada um com carabina e combustível tocando fogo nas casas. Lá tem cemitério, lá tem tudo que pode contar história. Resumindo, em 2000, agora bem recente, depois que fui líder comunitário pela cidade e tal, foi no ano de 2000 tentei retomar as terras lá, e por várias pessoas dali mesmo. E como nós temos sitiozinho bem vizinho, aonde tem 37 famílias hoje, pelo lado das terras eu achei que a gente poderia pegar essas terras de volta. E eu tive que ser escoltado quase um mês para poder viver, a peãozada dos donos das terras não se rendeu, a dificuldade no ano 2000. Só 2002 depois que o Lula assumiu a presidência da república é que nós começamos a ter vez que aí ligaram para mim "Sr. Emídio manda o relatório tal”. Aí mandei para Brasília, aí que nós fomos reconhecidos. Começar a ser reconhecido, então, escancarou, quando ele fala que Governo Lula para cá escancarou a porta é verdade. Nós nunca tivemos reconhecimento de direitos nossos como é sequestrado todos os nossos direitos, quer dizer, então uma história assim é semelhante a todos aqui. Você entendeu, então é, nós continuamos nas dificuldades, se nós quilombolas não nos unirmos, 95\% de nossas terras que ficaram nas terras dos fazendeiros e latifundiários. Esses fazendeiros que tomaram nossas terras dizem que compraram, mas não é verdade, tomaram à força. Ele só tem 36 fazendas em Mato Grosso. Só. 24 são nas áreas devolutas. Quem que sabe que ele não é dono de terra em volta de cada comunidade aí são 66, quem que sabe que ele mantém. Porque é dos Gover- 
nos que tinham o mapa, o mapeamento do Estado. E eles que sabiam onde eram as áreas devolutas. Então eles que facilitavam para aqueles que vinham da Turquia, que vinham lá do Sul do Brasil, que vinham com a mala preta e compravam as terras do próprio Estado, daqueles que governava o Estado a preço de banana e chegavam com toda a força tomando de nossos ancestrais, do nosso povo, você entendeu, quer dizer, são os próprios governantes desde essa época, vou falar de 73 para cá, né, porque eu sou prova viva, porque eu digo, nossos currais, nós andávamos de boi em volta da Serra lá buscando o gado nosso. Nós tínhamos pouco gado, nós tínhamos mais de 100 cabeças de boi, meus pais e minha família. Rebanho de animais, quer dizer, ficamos sem nada praticamente porque até que começamos, quer dizer, foi comendo aos poucos isso aí, acabou com tudo, quer dizer, assim são várias outras famílias. Então é incrível, se a gente for pegar a história mesma de cada um aqui, se nós não nos unirmos, eu acho muito louvável isso aqui, está realmente, da comunidade que eles têm, nasceram e criaram lá, mas uma próxima, por exemplo, professora pode, pode tentar buscar uns apoiadores para trazer mais comunidades. Poconé tem mais de dez, Livramento. O meu pai dia 3 de janeiro faz 98 anos. Ele nasceu lá, nessas terras que os latifundiários tomaram de nós, mas ele mora bem ao lado das terras até hoje. Ele ficou, pegou um pedacinho lá pertinho e fica por lá mesmo. Eu me lembro no dia de Nossa Senhora da Imaculada Conceição que é amanhã (8/12/2013) todos nós somos devotos de Nossa Senhora da Imaculada Conceição. A festa começava e durava dois dias, começava dia 7 para o dia 8 e ia até dia 9. Aí no dia do Glorioso Bom Jesus que é do dia 31 para primeiro e ia até no dia três, dia do aniversário dele toda a redondeza. Era três, quatro, cinco vacas que matavam, ele era cururueiro, tocava muito a viola e também era capelão. Aí que foi de setenta e quatro (1974) para cá ele parou de fazer as festas tudinho por causa disso aí (Emídio de Souza).

No final da manhã, Berchman Leite Ribeiro, após ouvir o longo relato de Emídio, do quilombo Morro do Cambambi, retomou a palavra, suscitado pelas memórias dos outros em torno das festas e dos conhecimentos sobre plantas e rezas. Ele ressaltou a sua participação na produção da pesquisa etnográfica para a elaboração dos laudos antropológicos coordenados pelo INCRA:

Professora, eu fiz um trabalho de como nós vivemos, a água que nós tomamos, a estrada que nós passamos, as madeiras que nós usávamos para fazer canoa porque não tinha motor e não tinha estrada. É, a madeira que nós usávamos para fazer remo. As frutas que nós usávamos para nos alimentar, o que usava para fazer remédio, foi registrado tudinho no cartório, mandei tudinho para lá. Está tudo registrado. O que nós vivemos, como nós vivemos, e como estava. Aí peguei a lista dos mortos, de uma sepultura, de todos que morreram, os cemitérios todinhos e está aqui nesse mapa aqui os cemitérios que foram enterrados, as famílias que estão lá, quem morou primeiro e até hoje (Foto 2). Como é que saíram e por que, entendeu. Fiz esse relatório todinho. Está com eles. A antropóloga, ela pediu para quando eles viessem primeiro a Renata, eles foram comigo lá, aí depois eles pegaram os dados que a gente mandou, através da reunião que eles fizeram já aproveitaram e fez um documento ali também para ajudar. E aí quando essas outras chegaram eu também fui de ponta a ponta com eles, ficou eu e o Pedro, o presidente, nós fomos de ponta a ponta naquela terra onde a gente trabalhou daqui, foi de ponta a ponta lá dentro. E na Bela Cor (outra comunidade quilombola), o Pedro foi de ponta a ponta. Entendeu? Então tornou-se mais fácil, o camarada falou: "Ah, os caras vão te matar, é mais um”. Não me importo, mas se morrer, morreu hoje está 
com um milhão de anos que morreu, quando eu vi eles estão andando. Está desse jeito, deixa com nós. O que acontecer hoje, aí estou acreditando, estou acreditando, aí essa festa eu quero que a gente faça. Como que meu pai vivia, o que eles trabalhavam, entendeu, lá onde nós morávamos, lá era assim o alambique de pinga, melado. Eu fui lá e mostrei para a antropóloga, aonde que nós fazíamos, as estradas no fundo da roça, nós andamos na água por aqui assim (mostrando no corpo onde a água batia), lá em cima no prédio do prefeito aqui, nós andamos quase três quilômetros, nós fomos lá dentro dos prédios. A D. Mari, todas essas ruínas de negros, andamos todos no rio de ponta a ponta. Nós fomos tudinho. Mas tem outro detalhe, tem mais outro detalhe, que os negros, eu vou falar de mim, nós o povo nosso lá, fugiu do que eles eram, um pouco, só um pouco, porque, porque não tem esse conhecimento que está tendo agora. Do que você foi, o que vocêpode ser, como? Nós vivíamos tudo em Vila Bela, nós não tínhamos médico, lá não tinha enfermeiro, nós vivíamos abandonados, ficamos 100 anos abandonados lá, 100 anos! Esquecidos (Berchman Leite Ribeiro).

Além da devolutiva, o seminário ensejava pensar a proposição de um programa de inclusão de estudantes quilombolas tomando como referência o Programa de Inclusão Indígena (o PROIND) na UFMT. Após a exposição da experiência das políticas de ação afirmativa para estudantes indígenas do estado de Mato Grosso, ouvimos as narrativas que os representantes das oito comunidades quilombolas fizeram ao longo do dia. Eles e elas destacaram os processos históricos de exclusão, de violência racial, de confinamento territorial, das ameaças contra a vida de lideranças, do abandono das comunidades negras pelo Estado e as dificuldades que os jovens estudantes quilombolas têm para acessar os processos de ingresso no ensino superior por meio da Lei de Cotas no ${ }^{\circ}$ 12.711/2012. No final do dia, decidiram, por unanimidade, encaminhar uma carta à Reitoria da UFMT, solicitando a viabilização de um Fórum para a discussão de uma política de acesso ao Ensino Superior na UFMT (Foto 2).

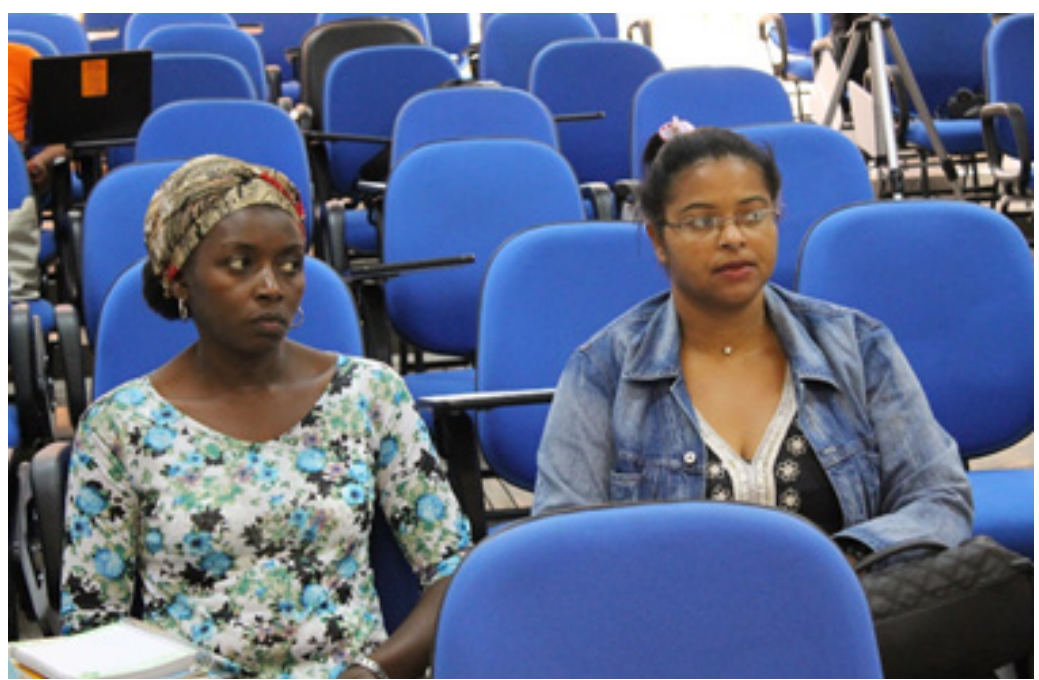

Foto 2: Rosária (quilombo Tanque do Padre, Poconé) e Maria Patrícia de Souza (Cambambi, Chapada dos Guimarães), Seminário Comunidades Quilombolas de Mato Grosso: território, educação e patrimônio cultural, 07 de dezembro de 2013, ICHS, UFMT. Acervo Pessoal.

A avaliação dos quilombolas ressaltou que a Lei $12.711 / 2012$ não estava contemplando as especificidades históricas, étnicas, culturais e políticas dos jovens quilombolas, em outras palavras, a po- 
lítica de cotas raciais não contemplava toda a pluralidade étnica-cultural própria das 97 comunidades quilombolas, situadas nas áreas rurais e nas áreas periféricas das cidades do estado de Mato Grosso.

$\mathrm{Na}$ carta reivindicaram que, para a concretização do Fórum, seria fundamental a abertura de um espaço de diálogo e reflexão dentro da Universidade e o apoio para que os representantes destas comunidades participassem do processo de discussão, em conjunto com a Pró-Reitoria de Assistência Estudantil (PRAE), responsável pela implementação de Políticas de Ações Afirmativas, tendo em vista a criação de um programa específico para atender as demandas de acesso ao Ensino Superior. A carta foi entregue à Reitoria da UFMT por mim, docente do Departamento de Antropologia, de acordo com os procedimentos legais e processuais da universidade. A partir de 2014, a proposta teve uma série de desdobramentos que serão tratados ao longo deste texto.

As ações afirmativas na Universidade Federal de Mato Grosso (UFMT) foram construídas nos últimos quatorze anos com a participação de diversos grupos sociais, povos indígenas, quilombolas e representantes da comunidade acadêmica, movimentos sociais do estado de Mato Grosso que reivindicaram da universidade a proposição e a criação de políticas públicas de acesso e permanência no ensino superior. As ações afirmativas como constitutivas de políticas públicas no ensino superior criadas na UFMT estão amparadas na Carta Constitucional, no marco legal vigente do ensino superior e nas resoluções aprovadas pelo Conselho de Ensino, Pesquisa e Extensão (CONSEPE), órgão superior e deliberativo da universidade.

O PROINQ é o quinto programa de ação afirmativa, mas o primeiro programa considerado uma referência e parâmetro de política de inclusão é o Programa de Inclusão Indígena Guerreiros da Caneta/ PROIND, aprovado pela Resolução CONSEPE n. ${ }^{\circ}$ 82, de 12 de setembro de 2007, que criou o programa com 100 vagas suplementares, pautadas na demanda de 42 povos indígenas do estado de Mato Grosso (Serra \& Silva 2011: 20-21). O segundo programa de ação afirmativa criado na UFMT foi destinado aos estudantes egressos de escola pública e estudantes negros, instituído com a Resolução CONSEPE $n^{\circ}$. 97, de 31 de outubro de 2011. O programa reservou 50\% das vagas em todos os cursos de graduação; destas, $30 \%$ para estudantes egressos de escolas públicas, e $20 \%$ para estudantes negros egressos de escolas públicas. O ingresso de estudantes se efetivou com a matrícula de estudantes "cotistas" em 2012. No ano seguinte, a UFMT cumpriu a recomendação do Ministério Público Federal e implementou o processo seletivo específico de 2012, com a oferta de 276 vagas suplementares para estudantes negros de famílias de baixa renda em todos os cursos de graduação regulares e presenciais da UFMT.

O terceiro programa de ação afirmativa foi instituído com a Lei 12.711, de 29 de agosto de 2012, que dispôs sobre o sistema de reserva de 50\% de vagas para ingresso de estudantes de escola pública, com recorte de renda e a autoidentificação por cor/raça (pretos, pardos e indígenas) nas universidades federais, institutos federais de ensino técnico e de nível médio. Esse programa foi instituído pela 
Resolução CONSEPE nº. 98, de 13/11/2012, que realizou a adequação do Programa de Ação Afirmativa criado no ano anterior. ${ }^{5}$

O Programa de Inclusão de Estudantes Quilombolas é instituído com a Resolução CONSEPE $\mathrm{n}^{\circ}$. 101, de 26 de setembro de 2016. Para a criação dessa política acadêmica, a Coordenação de Políticas Acadêmicas e Ação Afirmativa da PRAE mobilizou docentes e discentes, movimentos sociais, núcleos de pesquisa, representantes indígenas e quilombolas para a formação do Conselho de Ações Afirmativas da UFMT, um órgão consultivo e avaliativo voltado para as políticas de inclusão e ações afirmativas na universidade. Lideranças quilombolas das comunidades dos municípios de Chapada dos Guimarães, Poconé, Barra do Bugres, Várzea Grande e Mata Cavalo participaram das reuniões que resultaram na criação do Conselho de Políticas de Ações Afirmativas da PRAE, em fevereiro de 2014, reafirmando a demanda das comunidades remanescentes de quilombos no estado de Mato Grosso.

A Coordenação de Políticas Acadêmicas e Ações Afirmativas (PRAE) propôs a realização do "I Fórum de Políticas de Ações Afirmativas para estudantes Quilombolas" para atender à solicitação dos quilombolas feita com a carta enviada à Reitoria de 8 de dezembro de 2013. Para tal, teve a colaboração dos núcleos de pesquisa NAPAS (Núcleo de Pesquisa em Antropologia, Arte, Performance e Simbolismo), vinculado ao Departamento de Antropologia, do Instituto de Ciências Humanas e Sociais (ICHS); NEPRI (Núcleo de Pesquisas de Relações Raciais e Educação), vinculado ao Instituto de Educação; e da Secretaria de Estado de Educação, Esporte e Lazer de Mato Grosso (SEDUC) para a identificação e convite de lideranças quilombolas das 97 comunidades remanescentes de quilombos no estado de Mato Grosso. As lideranças receberam um questionário para identificar quais os cursos que interessavam aos estudantes e, assim, apresentar um quadro com as demandas no Fórum.

No dia 12 de julho de 2014, realizamos o I Fórum de Politicas de Ações Afirmativas para Estudantes Quilombolas com a participação de representantes de 55 comunidades quilombolas de oito municípios (Foto 3) do estado de Mato Grosso. ${ }^{6}$ O evento teve a participação do Diretor de Políticas em Educação no Campo do Ministério da Educação (MEC) e da Gerência de Diversidades Educacionais da Secretaria de Estado de Educação, Esporte e Lazer de Mato Grosso (SEDUC). O Fórum privilegiou a escuta das lideranças presentes, que puderam expor suas narrativas que versaram sobre os trezentos anos de história de exclusão de direitos e de acesso às políticas de educação, saúde, moradia e o direito à titulação das terras de quilombo também denominadas terras de preto, terras de santo e terras de uso comum (Leite 2000, 2008, 2012; Santos 2010; O’ Dwyer 2002, 2010; Almeida 2004; Arruti 2006; Mello 2012).

\footnotetext{
5 O quarto programa de ação afirmativa é voltado para as pessoas com deficiência auditiva em conformidade com o Decreto $\mathrm{n}^{\circ}$. 5.626/2005, que regulamenta a Lei no ${ }^{\circ}$ 10.436, de 24 de abril de 2002, que dispõe sobre a Língua Brasileira de Sinais - Libras, e o art. 18 da Lei $n^{\circ}$. 10.098, de 19 de dezembro de 2000, no Processo Seletivo Especial para ingresso no curso de Graduação Letras-Libras, Licenciatura, do Departamento de Letras, do Instituto de Linguagem do Campus Universitário de Cuiabá, a partir de 2014, conforme Resolução CONSEPE nº. 02, de 23/01/2014, e a Resolução CONSEPE nº. 128, de 15/12/2014 (Fonte, PRAE, 2016).

6 Todos os quilombolas receberam passagens rodoviárias de ida e volta, hospedagem e alimentação completa no Hotel Fazenda Mato Grosso, custeadas pela Universidade Federal de Mato Grosso.
} 


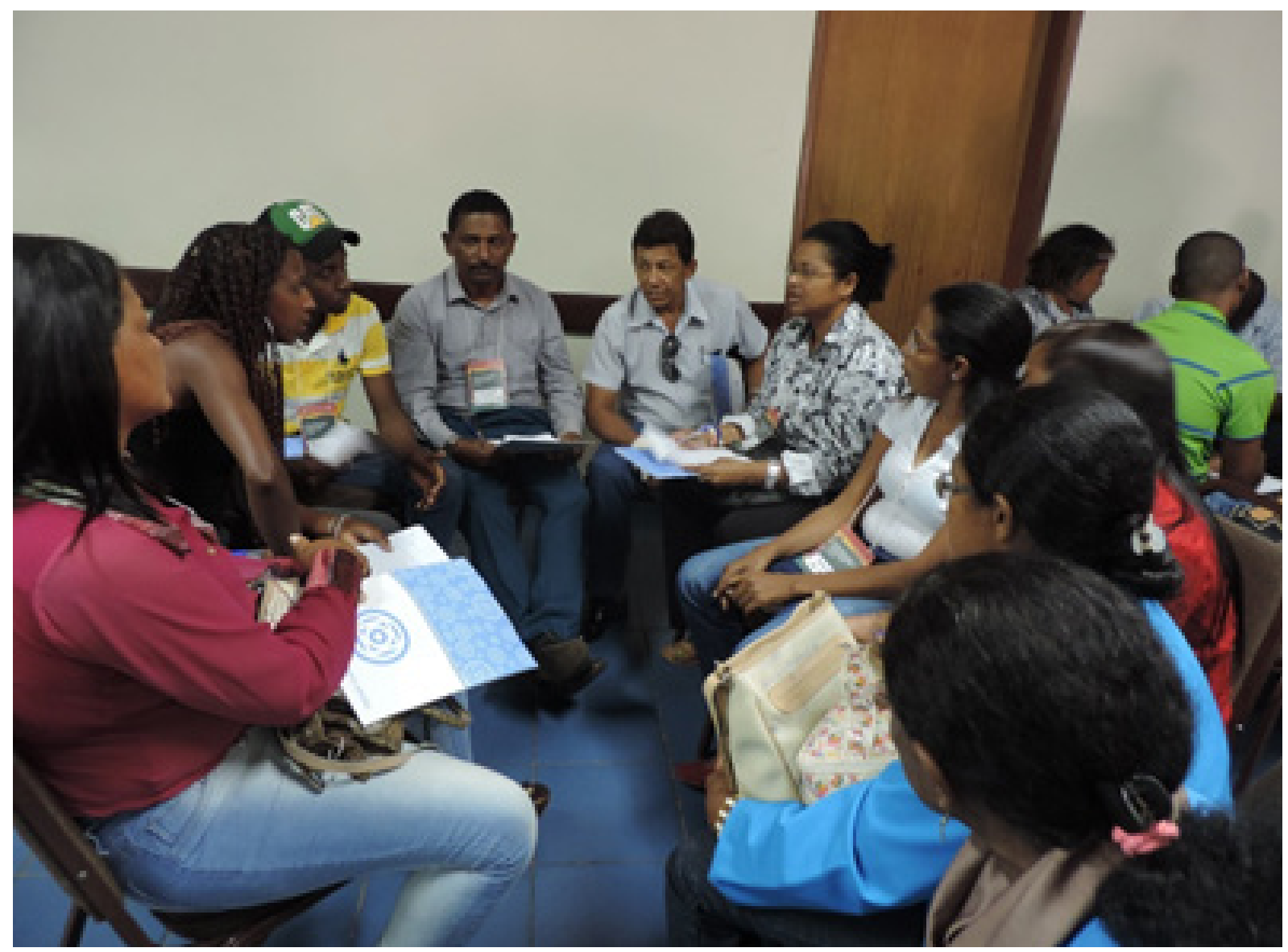

Foto 3: Lagoinha de Baixo, Lagoinha de Cima e Serra do Cambambi, Chapada dos Guimarães. I Fórum de Políticas de Açóes Afirmativas para estudantes Quilombolas foi realizado em 27 de junho de 2014. Acervo Pessoal.

A dinâmica adotada para que as comunidades ali presentes pudessem identificar quais os cursos de ensino de graduação, licenciatura ou bacharelado interessavam aos jovens quilombolas foi a formação de grupos de trabalho com representantes de quilombos por regiões e municípios. Depois de uma hora de trabalho, cada grupo teve um tempo para expor suas demandas para a universidade. $\mathrm{O}$ Gráfico 1, elaborado pela equipe da PRAE (2014), mostra que, dos 40 cursos indicados, os seis primeiros cursos de bacharelado escolhidos como preferenciais foram os de direito, medicina, pedagogia, medicina veterinária, serviço social e engenharia florestal, cursos que, na perspectiva dos quilombolas, poderão atender às demandas no âmbito das políticas públicas voltadas para o direito aos territórios tradicionais, a saúde, a educação, o meio ambiente, as artes e as letras. Na perspectiva dos quilombolas, depois da conclusão dos cursos de graduação, os jovens deverão voltar para as suas comunidades e desenvolver as suas habilidades e conhecimentos apreendidos na universidade. A ideia defendida nos fóruns e reuniões pelas lideranças dos quilombos é que os jovens que serão indicados para estudar na universidade tenham o compromisso estabelecido com a coletividade de suas comunidades. Isso significa que o investimento político nas ações afirmativas tem em vista a contrapartida do retorno dos futuros bacharéis ou licenciados pela UFMT com o trabalho na e para as comunidades. 


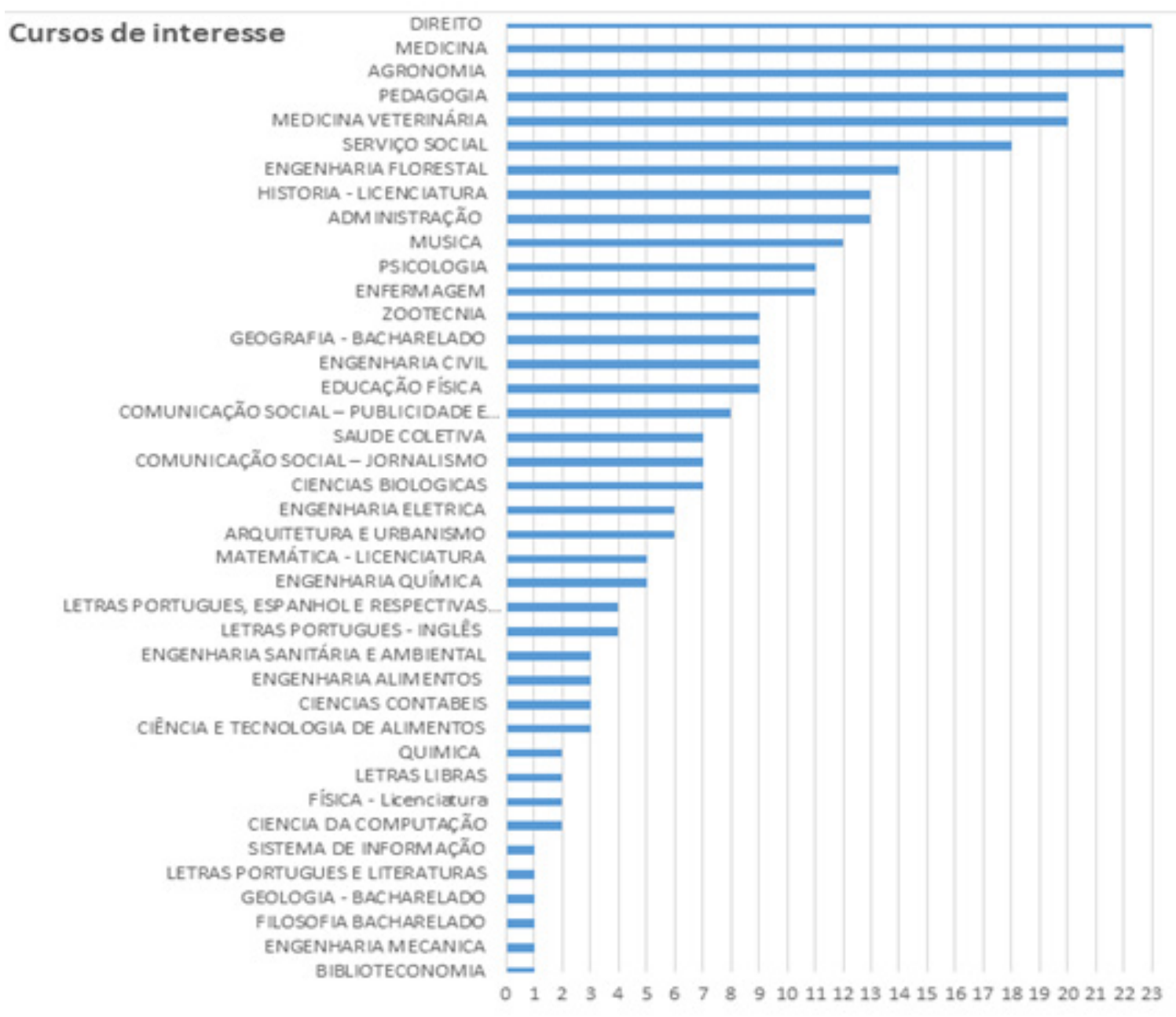

Gráfico 1: Os cursos de maior interesse indicados pelas comunidades. Fonte: PRAE, 2014.

O levantamento geral mostra que o interesse pelos cursos foi abrangente ao abarcar quase todas as áreas de conhecimento - ciências humanas, ciências exatas e da terra, ciências da saúde, ciências biológicas, engenharia/tecnologia, linguística, letras e artes -, consideradas as 1.500 por vagas suplementares que seriam distribuídas em cinco anos.

No final do fórum, formou-se um grupo com representantes das comunidades quilombolas presentes para uma reunião posterior na PRAE com vistas a consolidar as demandas e ratificar a proposta de criação do PROINQ. A reunião aconteceu no mês de agosto de 2014 e nela foi ratificado o total de 1.500 vagas a serem distribuídas em todos os cursos de ensino de graduação da UFMT, nas modalidades de licenciatura e bacharelado, ou seja, a criação de vagas suplementares com o máximo de duas vagas para cada curso. Assim, durante cinco anos, as 1.500 vagas suplementares seriam divididas em 200 vagas no primeiro ano, 250 vagas no segundo ano, 350 vagas no terceiro ano, 350 vagas no quarto ano e 350 vagas no quinto ano.

Durante todo o ano de 2014, foram realizadas reuniões do Conselho de Ações Afirmativas com a pauta focalizando a criação do PROINQ. Em 13/10/2014 foi realizada a I Reunião com a Comunidade Universitária sobre a Política de Ação Afirmativa para Estudantes Quilombolas da UFMT, com a finalidade de apresentar, explicar e defender o projeto de criação do programa, tendo como referência a par- 
ticipação das comunidades quilombolas que se envolveram na formulação desta política de ação afirmativa, de forma coletiva e conjunta com a universidade. A reunião teve a participação da Pró-Reitora de Assistência Estudantil, da Pró-Reitora de Graduação, de estudantes, professores, diretores e coordenadores de cursos de graduação, conselheiros do Conselho de Políticas de Ações Afirmativas da PRAE e lideranças de comunidades quilombolas.

A questão principal era mostrar a importância da criação do PROINQ como política pública para além da Lei de Cotas, contextualizar, do ponto de vista antropológico, a situação das comunidades quilombolas no estado de Mato Grosso, destacando, além da existência de 97 quilombos, as diferenças culturais entre eles, as pautas de reivindicações por direitos, e por que as cotas raciais não contemplavam as demandas dos quilombos. A reflexão apresentada focalizou que as comunidades quilombolas são consideradas, na perspectiva antropológica, como "grupos étnicos" organizados socialmente, que estabelecem fronteiras culturais por meio da seleção de sinais diacríticos e práticas sociais que permitem aferir que não são necessariamente heranças de quilombos históricos (Gomes \& Reis, 1996; Gomes, 2015) que precisariam de evidências arqueológicas para provar sua "legitimidade", ou que deveriam corresponder ao modelo de quilombo "a la Palmares" (Barth 2000). Neste horizonte, se apresentou a definição formulada por Ilka Boaventura Leite, que sintetizou uma compreensão mais ampla das terras de quilombos, propondo que estas correspondem

\footnotetext{
“[à]s áreas territoriais identificadas pelos grupos negros como experiências específicas consolidadas por meio de vínculos sociais e históricos, e noções de pertencimento e origem comum presumida, convergindo para uma territorialidade expressa como modalidades próprias de organização social, parentesco, sociabilidade e valores culturais materiais e imateriais de um patrimônio reconhecido pela coletividade que a integra" (Leite 2012:357).
}

Apresentar a compreensão antropológica sobre os quilombos contemporâneos foi uma forma de explicar as razões de criação do PROINQ, pondo em evidência uma abordagem mais plural acerca da diferença e da etnicidade que caracterizam, mas não encerram, as organizações quilombolas. A preocupação era em que medida poderíamos compartilhar um entendimento acerca dos quilombos no cenário de formulação de uma política pública que não se limitasse à lógica da unificação do Estado (Clastres 2003:234) que, ao acolher a diversidade cultural, tende a cristalizar a Multiplicidade no Um, a produzir versões homogêneas sobre a diferença. E este é o risco de toda política pública quando propõe programas e ações de alcance geral para amplas e heterogêneas realidades de povos tradicionais como os povos indígenas e quilombolas.

As perguntas dos participantes eram concernentes à definição de quilombos. Assim, destacamos que nos últimos trinta anos a antropologia tem considerado o que é socialmente e significativamente relevante para os grupos, ou seja, a definição de quilombos é tributária, em primeiro lugar, dos modos pelos quais as comunidades quilombolas definem suas identidades étnicas a partir de suas diferenças culturais, diferenças que são escolhidas pelo grupo em sua autodefinição como "remanescentes de comunidades de quilombos” e/ou “comunidades negras". Conforme O’Dwyer “a construção de uma 
identidade originária dos quilombos torna-se uma referência atualizada em diferentes situações nas quais os grupos se mobilizam e orientam suas ações pela aplicação do artigo 68 do ADCT" (O'Dwyer 2010:21), ressemantizando-o.

Desta forma, ressaltava-se a variabilidade de sentidos que o termo quilombo transporta. O estudo de Leite (2012: 358) aponta que "o termo quilombo como um direito apresenta na terminologia jurídica variações nas expressões locais e regionais, entre as quais "terras de preto", "territórios negros", “terras de santo", “mocambos”, “comunidades negras”. Vale destacar que o Decreto nº 4.887/2003 ampliou os sentidos ao incluir não somente áreas rurais, mas também bairros e pequenas unidades domiciliares nos grandes centros e periferias urbanas onde se encontram centenas de famílias que foram desterritorializadas pelas forças do agronegócio e da expansão das grandes cidades, ao longo das últimas décadas.

No final da reunião, foi deliberada a realização do II Fórum de Políticas de Ações Afirmativas para estudantes quilombolas da UFMT, com a apresentação do projeto PROINQ pela PRAE e posterior apresentação às demais instâncias acadêmicas, à Câmara de Graduação, vinculada à Pró-Reitoria de Ensino de Graduação, e ao CONSEPE. Se o programa fosse aprovado o primeiro processo seletivo seria em 2015. No ano seguinte, o II Fórum de Políticsa de Açóes Afirmativas para estudantes Quilombolas na UFMT aconteceu em 8 de maio de 2015, com a participação da comunidade universitária e das comunidades quilombolas para referendar a criação do Programa de Inclusão Quilombola.

A existência de famílias quilombolas nas cidades ensejou uma dúvida entre os participantes das reuniões e do II Fórum, porque, até então, algumas lideranças quilombolas e do movimento social pensavam que as ações afirmativas deveriam ser destinadas apenas aos jovens residentes dentro dos territórios das áreas rurais, e que os jovens residentes nas cidades disputariam as vagas originárias das cotas raciais. A tensão criou a possibilidade de destacar que uma política de ação afirmativa pensada para a inclusão não poderia criar dentro de si um mecanismo de exclusão. Em outras palavras, quais seriam os parâmetros diacríticos para determinar quem teria direito às vagas suplementares: aqueles residentes em áreas rurais porque seriam "mais quilombolas", "mais tradicionais", porque tiveram uma formação no ensino fundamental e médio mais precária que os residentes nas cidades considerados "menos envolvidos" com a vida dos quilombos? No final dos debates, após a exposição de diferentes contextos etnográficos dos quilombos no Brasil, o entendimento convergiu para uma política que incluísse todos os jovens quilombolas, residindo ou não nos territórios quilombolas (exíguos, pequenos, não demarcados e não titulados).

Além disso, a conceitualização dos quilombos como grupos étnicos permitiu ressaltar que as pautas dos quilombos não eram as mesmas que as do movimento negro brasileiro. Embora o segundo tenha tomado o quilombo como símbolo de resistência contra o racismo no Brasil, como o termo "quilombismo" formulado por Abdias Nascimento (1980), as comunidades quilombolas ressaltaram que os processos de exclusão por elas vividos historicamente ultrapassavam as questões "raciais", ou não se encerravam nela. Em outras palavras, termos como "negros", "pretos", que antes os estigmatizavam, agora são adotados com novos significados e sentidos nas fronteiras culturais, mobilizando o discurso 
identitário como quilombolas, reafirmando-se como grupos socialmente organizados, alicerçados na memória genealógica e territorial, no parentesco e nas suas práticas sociais.

Durante o ano de 2015, o processo de criação do programa teve vários momentos tensos em que foi necessária uma mobilização das comunidades quilombolas, do Coletivo Negro Universitário, dos estudantes indígenas do PROIND que, durante todo o processo, apoiaram de forma incondicional a ação afirmativa para os jovens quilombolas na universidade, de docentes e discentes, do Conselho de Ações Afirmativas da UFMT, todos articulados em defesa do PROINQ como um direito fundamental e constitucional da população "remanescente de quilombos" ao ensino superior. O projeto de criação do PROINQ seguiu os procedimentos protocolares em diversas instâncias da UFMT para que fosse aprovado e, assim, pudesse abrir a primeira turma de estudantes em 2017.

A criação desta política de ação afirmativa para jovens quilombolas sofreu os reveses de discursos permeados de conteúdo racista e meritocrático, utilizando-se da micropolítica da procrastinação na avaliação do projeto, ou seja, o pedido de vistas ao processo durou mais de três meses e fez com que o programa demorasse a ser avaliado e aprovado nas instâncias devidas. Nesse ínterim, as universidades federais entraram num longo período de quatro meses de greve, culminando com o processo de impeachment da Presidenta da República, Dilma Rousseff, e a intensificação de projetos políticos contrários ao Estado Democrático de Direito, configurando um cenário de dissolução de políticas públicas em vigor destinadas à educação que estavam em vias de se consolidar, além das tentativas de alteração dos direitos de povos indígenas e comunidades quilombolas, estabelecidos e até então assegurados na Constituição Federal de 1988.

As ações de mobilização durante os debates na Câmara de Ensino de Graduação e no CONSEPE possibilitaram que as lideranças quilombolas, os representantes dos núcleos de pesquisa (NAPAS, NEPRI), o Coletivo Negro Universitário, os estudantes indígenas e demais docentes e discentes da universidade pudessem se posicionar em defesa da perspectiva dos jovens quilombolas em reconhecer o PROINQ como um direito da população quilombola no Brasil de acesso ao ensino superior público, reafirmando que "as ações afirmativas são medidas que visam criar oportunidades iguais para grupos e populações excluídas do ponto de vista social" (Santos 2012: 212).

O processo de criação do PROINQ abriu na UFMT várias possibilidades e espaços de reflexividade e de debates, em que a comunidade acadêmica passou a conhecer as diversas e diferentes realidades das comunidades quilombolas com elas ali presentes, posicionando-se como sujeitos e afirmando suas perspectivas de autodeterminação em toda sua potência. A cosmopolítica do quilombo passou a permear o território da universidade.

Em setembro de 2017, a UFMT conseguiu aprovar, nas instâncias superiores, a criação de cem vagas suplementares para o primeiro processo seletivo de 2017, considerando a importância de propiciar condições de permanência dos estudantes na universidade por meio do Programa Bolsa Permanência do MEC (PBP-MEC). As duzentas vagas inicialmente reivindicadas para o primeiro ano não foram contempladas na integralidade, porque uma das premissas da ação afirmativa é garantir a permanência dos estudantes na universidade. Assim, as condições reais permitiram a criação de cem vagas suplementares, o apoio do Programa Bolsa Permanência e o acompanhamento acadêmicos dos 
estudantes por docentes do quadro da universidade e da Coordenação de Políticas Acadêmicas e Ações Afirmativas da PRAE.

O primeiro vestibular (Edital n..$^{\circ}$ 07/2017) para candidatos(as) quilombolas do estado de Mato Grosso priorizou os(as) candidatos(as) portadores de certificado de conclusão do Ensino Médio ou equivalente, ou que comprovassem a conclusão do Ensino Médio na data da matrícula, e que não fossem contemplados com programas específicos e/ou diferenciados de instituições públicas de ensino superior. $\mathrm{O}$ edital considerou os remanescentes das comunidades dos quilombos a partir do conceito antropológico de grupos étnicos, formulado por Fredrik Barth (2000), segundo critérios de autoatribuição, com trajetória histórica própria, dotados de relações territoriais específicas, com presunção de ancestralidade negra relacionada com a resistência à opressão histórica sofrida, definidos no art. $2^{\circ}$ do Decreto $n^{\circ}$ 4.887, de 20 de novembro de 2003, e no Ato das Disposições Transitórios 68, da Carta Constitucional.

A forma de realização do vestibular foi tema de reflexão e articulação com a Secretaria de Estado de Educação, Esporte e Lazer de Mato Grosso (SEDUC), que assinou o Termo de Convênio n. ${ }^{\circ}$ 010/FUFMT/2017 com a Fundação Universidade Federal de Mato Grosso para que as inscrições fossem realizadas nas escolas selecionadas pela SEDUC, com o apoio de profissional responsável e/ou dirigentes das escolas dos municípios de Barra do Bugres, Vila Bela da Santíssima Trindade, Nossa Senhora do Livramento, Chapada dos Guimarães, Santo Antônio do Leverger, Distrito de Chumbo Poconé, Poconé e Várzea Grande para coordenar as inscrições.

A documentação que assegurou que apenas candidatos quilombolas fizessem a inscrição no vestibular específico foi a entrega da Declaração de Pertencimento Étnico Quilombola, assinada por pelo menos três lideranças reconhecidas pela comunidade, que, durante o ato de matrícula, foi analisada por Comissão designada pela Pró-Reitoria de Assistência Estudantil.

No dia 21 de agosto, começaram as inscrições para o preenchimento de cem vagas suplementares dos campi de Cuiabá, Araguaia, Rondonópolis e Várzea Grande, em diferentes cursos de ensino de graduação, bacharelado e licenciatura. As cem vagas foram disputadas por 501 candidatos inscritos que realizaram as provas Objetiva, de caráter eliminatório e classificatório, e a Prova de Redação, também de caráter eliminatório e classificatório. Do total de inscritos, 73 foram aprovados e fizeram a matrícula, realizada de 11 a 15 de setembro com a participação de estudantes indígenas do PROIND, bolsistas e estudantes da pós-graduação em Antropologia que colaboraram com os novos estudantes, explicando como preencher os formulários e fornecendo as orientações necessárias para que pudessem, enfim, situar-se no espaço acadêmico da UFMT.

A partir dessas considerações, defender ações afirmativas para os estudantes das comunidades de quilombos no ensino superior atende não somente aos direitos inscritos em nossa Carta Constitucional de 1988, mas ao reconhecimento dos quilombos como grupos étnicos e sujeitos de direito, porque as ações afirmativas "preveem diferentes formas de execução e têm como objetivo promover maior inserção [entrada e permanência] desses grupos [indígenas, quilombolas, por ex.] e populações seja nos sistemas de saúde e educação, seja no mercado de trabalho" (Santos 2012: 212; acréscimos meus). 
As divergências existentes e ações contrárias às ações afirmativas para a população negra, indígena e quilombola no Brasil perpassam as universidades e toda a sociedade brasileira. A resistência se manifesta nos argumentos da "meritocracia individual" negada pelo sistema de cotas, a reiteração de que o Brasil é um país mestiço ou ainda pelos argumentos jurídicos de que "a regulamentação de cotas" é o reconhecimento da existência da discriminação do ponto de vista legal (Santos 2012:215). Estes três argumentos permearam os discursos de resistência ao Programa de Inclusão de Estudantes Quilombolas na UFMT.

Os segmentos mais conservadores e contrários às ações afirmativas que incluem, além do sistema de cotas, as bolsas de estudo de Iniciação Científica PIBIC/Ação Afirmativa, bolsas de extensão em editais de Ação Afirmativa, programas de bolsa permanência, entre outros, se pautam na ideia-valor do indivíduo (Dumont 1985) e do mérito daqueles considerados "naturalmente" sujeitos de direito.

As políticas públicas para a educação, para além do reconhecimento de que a sociedade brasileira é pluriétnica, precisam considerar que o direito à igualdade não prescinde do direito à diferença. $\mathrm{O}$ direito à diferença e o direito à igualdade são dois planos tensos, ambivalentes, relacionais e, simultaneamente, complementares na medida em que apontam para as relações de força entre segmentos sociais como as comunidades quilombolas e o Estado. Isso não significa que não possamos superar essas tensões e trilhar os caminhos para a inclusão social e a cidadania de estudantes quilombolas, indígenas, negros e negras, transgêneros e estudantes oriundos das periferias das grandes cidades e dos sertões do Brasil.

\section{Sônia Regina Lourenço é doutora em Antropologia Socialpelo PPGAS/UFSCe professora e coordenadora do PPGAS da Universidade Federal do Mato Grosso (UFMT).}

\section{REFERÊNCIAS BIBLIOGRÁFICAS}

ALMEIDA, Alfredo Wagner Berno de. 2004. Terras tradicionalmente ocupadas: processos de territorialização e movimentos sociais. Revista Brasileira de Estudos Urbanos e Regionais 6(1): 9-32. ANZAI, Leny Caselli \& AMADO, Janaína (orgs.). 2016. Anais de Vila Bela. 1734-1789. Documentos Setecentistas: História. Cuiabá, MT: Carlini \& Caniato; EdUFMT.

ARRUTI, José Maurício A. P. 2006. Mocambo: Antropologia e história do processo de formação quilombola. Bauru, São Paulo: Edusc.

BANDEIRA, Maria de L. 1988. Território negro em espaço branco. São Paulo: Brasiliense.

BANDEIRA, Maria de L. 1991. Terra e territorialidade negra no Brasil contemporâneo. GT Temas e problemas da população negra no Brasil. XV Encontro Anual da ANPOCS, 15 a 18 de outubro, Caxambu, Minas Gerais.

BARTH, Fredrik. 2000. O guru, o iniciador e outras variações antropológicas (organização de Tomke 
Lask). Rio de Janeiro: Contracapa Livraria.

SILVA, Renata Bortoletto \& GIANOTTI, Simone. 2007. Relatório de Caracterização Sócio-Histórica e Antropológica Associação Quilombola Comunidade Negra Rural Lagoinha de Baixo, Chapada dos Guimarães (MT). Instituto Nacional de Colonização e Reforma Agrária (INCRA), Superintendência Regional de Mato Grosso SR/13, Cuiabá (MT).

DUMONT, Louis. 1985. O Individualismo. Uma perspectiva antropológica da ideologia moderna. Rio de Janeiro: Rocco.

CLASTRES, Pierre. 2003. A sociedade contra o Estado. São Paulo: Cosac \& Naify.

GOMES, Flávio dos Santos \& REIS, João José (orgs.). 1996. Liberdade por um fio: história dos quilombos no Brasil. São Paulo: Companhia das Letras.

GOMES, Flávio dos Santos. 2015. Mocambos e quilombos. Uma história do campesinato negro no Brasil. São Paulo: Editora Claro Enigma.

GOW, Peter. 1991. Of mixed blood: kinship and history in Peruvian Amazonia. Oxford Studies in Social and Cultural Anthropology. Oxford: Oxford University Press.

LEITE, Ilka B. 2000. "Os quilombos no Brasil: questões conceituais e normativas". Etnográfica 4(2): 333-354.

LEITE, Ilka B. 2008. “O projeto político quilombola: desafios, conquistas e impasses atuais”. Revista Estudos Feministas 16(3): 965-977.

LEITE, Ilka B. 2012. “Terras de quilombo”. In Antônio Carlos de Souza Lima (coord.). Antropologia ఓ Direito. Temas Antropológicos para estudos jurídicos. Rio de Janeiro/Brasília: Contra-Capa/LA$\mathrm{CED} / \mathrm{ABA}$.

NASCIMENTO, Abdias. 1980. O quilombismo. Documentos de uma militância pan-africanista. Petrópolis, RJ: Vozes.

MELLO, Marcelo Moura. 2012. Reminiscências dos quilombos. Territórios da memória em uma comunidade negra rural. São Paulo: Terceiro Nome.

O’DWYER, Eliane Cantarino (org.). 2002. Quilombos: identidade étnica e territorialidade. Rio de Janeiro. Editora FGV.

O’DWYER, Eliane Cantarino. 2010. O papel social do antropólogo. A aplicação do fazer antropológico e do conhecimento disciplinar nos debates públicos do Brasil contemporâneo. Col. Antropologias 6. Rio de Janeiro: LACED E-papers.

SANTOS, Jocélio Teles dos. 2012. "Ações afirmativas". In Antônio Carlos de Souza Lima (coord.). Antropologia \& Direito. Temas Antropológicos para estudos jurídicos. Rio de Janeiro/Brasília: Contra-Capa/LACED/ABA.

SANTOS, Carlos Alexandre Barboza Plínio dos. 2010. Fiéis Descendentes: redes-irmandades na pós-abolição entre comunidades negras rurais sul-mato-grossenses. Tese (Doutorado em Antropologia Social). Brasília: Universidade de Brasília. 


\title{
AÇÕES AFIRMATIVAS PARA ESTUDANTES QUILOMBOLAS: O PROCESSO DE CRIAÇÃO DO PROGRAMA DE INCLUSÃO DE ESTUDANTES QUILOMBOLAS NA UNIVERSIDADE FEDERAL DE MATO GROSSO (PROINQ)
}

Resumo: O artigo é um relato da experiência das políticas de ações afirmativas para estudantes de comunidades quilombolas no estado de Mato Grosso, construídas a partir do ano de 2013 na Universidade Federal de Mato Grosso. Descrevo a criação do Programa de Inclusão de Estudantes Quilombolas (PROINQ) como um processo aberto e plural, constituído com a participação intensa de diferentes representantes e lideranças quilombolas de 55 comunidades - reconhecidas pela Fundação Cultural Palmares como "comunidades remanescentes de quilombos" - e da comunidade universitária. Em setembro de 2017, quatro anos depois, a universidade abriu o primeiro processo seletivo específico para candidatos e candidatas de comunidades quilombolas do estado. Concluo com o entendimento de que as políticas públicas para a educação, para além do reconhecimento de que a sociedade brasileira é pluriétnica, só se consolidam de forma plena quando se considera que o direito à igualdade não pode prescindir do direito à diferença.

Palavras-chave: ações afirmativas; políticas públicas; ensino superior; quilombolas; Mato Grosso.

\section{AFFIRMATIVE ACTIONS FOR QUILOMBOLAS STUDENTS: THE PROCESS OF CREATION OF THE INCLUSION PROGRAM OF QUILOMBOLAS STUDENTS (PROINQ) AT THE FEDERAL UNIVERSITY OF MATO GROSSO (UFMT)}

\begin{abstract}
This article is an account of the experience of affirmative action policies developed from 2013 at the Federal University of Mato Grosso for students from quilombola communities in the state of Mato Grosso. I describe the creation of the Quilombola Student Inclusion Program (PROINQ) as an open and plural process, with intensive participation of quilombola representatives and leaders from 55 communities - recognized by the Palmares Cultural Foundation as "remaining communities of quilombos" - and of the university community. In September 2017, four years later, the university opened the first specific selection process for candidates from quilombola communities in the state of Mato Grosso. I conclude by arguing that education public policies, in addition to the recognition that Brazilian society is multi-ethnic, can consolidate only when it is taken into account that the right to equality cannot disregard the right to difference.
\end{abstract}

Keywords: affirmative action; public policy; higher education; quilombolas; Mato Grosso.

RECEBIDO: $07 / 11 / 2017$

APROVADO: $27 / 11 / 2017$ 
58 CAMpos V.17 N.2 jul.dez.2016 